\title{
An increased level of antibodies to $\beta$-lactoglobulin is a risk determinant for early-onset Type 1 (insulin-dependent) diabetes mellitus independent of islet cell antibodies and early introduction of cow's milk
}

\author{
G. Dahlquist $^{1}$, E. Savilahti ${ }^{3}$ and M. Landin-Olsson ${ }^{2}$ \\ ${ }^{2}$ Department of Pediatrics and Department of Epidemiology and Health Care Research, University of Umeả, ${ }^{2}$ Department of Internal \\ Medicine, University of Lund, Lund, Sweden and ${ }^{3}$ Department of Pediatrics, Helsinki University Hospital, Helsinki, Finland
}

\begin{abstract}
Summary. Using a case-control design we have studied whether antibodies to cow's milk proteins are risk determinants for childhood-onset Type 1 (insulin-dependent) diabetes mellitus independent of early exposure to cow's milk formula and islet cell antibodies. Sera from 116 recentonset diabetic children and 112 age-and sex-matched control children were analysed for cow's milk protein $\operatorname{IgA}, \operatorname{IgG}$ and IgM antibodies, $\beta$-lactoglobulin IgA and IgM antibodies and islet cell antibodies. The titres were compared to questionnaire data on duration of breast-feeding and introduction of formula feeding. Most antibody levels tended to be increased among diabetic compared to control children. This was statistically significant for cow's milk protein IgA antibodies $(p<0.001)$ and $\beta$-lactoglobulin IgA antibodies $(p<0.01)$ as well as for islet cell antibody-positivity which was found among $92 \%$ of the diabetic and $3 \%$ of control children. The differences in cow's milk protein antibodies as well as $\beta$-lactoglobulin antibodies were more pronounced among children with an early onset of Type 1 diabetes. Breast-feeding duration was significantly inversely related to the $\log$ of $\beta$-lactoglobulin IgG $(r=-0.16, p=0.04)$ and the $\log$ of cow's milk protein IgA antibodies $(r=-0.17, p<0.001)$. A positive correlation was found between formula feeding and the loga-
\end{abstract}

rithm of $\beta$-lactoglobulin IgG antibodies $(r=0.22, p=0.01)$ and the $\log$ of cow's milk protein IgA antibodies $(r=0.16$, $p=0.04$ ). In a multiple logistic regression analysis it was found that IgA antibodies to $\beta$-lactoglobulin and cow's milk protein were significantly related to the risk of Type 1 diabetes independent of islet cell antibodies. When introducing formula feeding before the age of 4 months as a variable in the regression it was shown that islet cell antibodies and $\beta$-lactoglobulin IgA antibodies were still significantly and independently related to an increased risk of diabetes whereas cow's milk protein IgA antibodies did not add further to the regression. It is concluded that $\beta$-lactoglobulin $\operatorname{Ig} \mathrm{A}$ antibodies are significantly associated with an increased risk of diabetes at a young age independent of islet cell antibodystatus and of an early weaning to cow's milk formula. In genetically susceptible children early exposure to $\beta$-lactoglobulin might be one trigger in the autoimmune process leading to development of Type 1 diabetes.

Key words: Type 1 (insulin-dependent) diabetes mellitus, children, $\beta$-lactoglobulin antibodies, cow's milk protein antibodies.
Increasing evidence suggests that the aetiology of Type 1 (insulin-dependent) diabetes mellitus is multifactorial. Genetic susceptibility seems to be a necessary but insufficient prerequisite for the development of the disease [1]. The repeated findings of social risk determinants for childhood diabetes $[2,3]$ indicate that lifestyle behaviour such as eating habits contribute to disease onset. In an ecological study it was shown that the mean milk consumption correlated to the yearly incidence of Type 1 diabetes [4]. Several studies have shown an association between a short duration of breast-feeding and childhood diabetes $[3,5,6]$ which indicates that an early introduction of cow's milk proteins may be a risk factor for early-onset Type 1 diabetes. This is supported by animal experiments which have shown that addition of cow's milk proteins into rat chow increases the incidence of diabetes in the diabetes prone BB-rat $[7,8]$.

In a Finnish study of Type 1 diabetic children [9], some of whom had been recently diagnosed, increased levels of cow's milk protein IgA antibodies and $\beta$-lactoglobulin $\operatorname{Ig} A$ and $\operatorname{IgG}$ antibodies were found when compared to age-matched healthy control children. This finding could be confounded by other exposure related to an earlier introduction of cow's milk protein. It could also be the result of a non-specific stimulation of the antibody response at the onset of Type 1 diabetes in which case it is probably associated with the presence of islet cell antibodies (ICA). 
Table 1. Levels of islet-cell antibodies (ICA), cow's milk protein antibodies and $\beta$-lactoglobulin antibodies

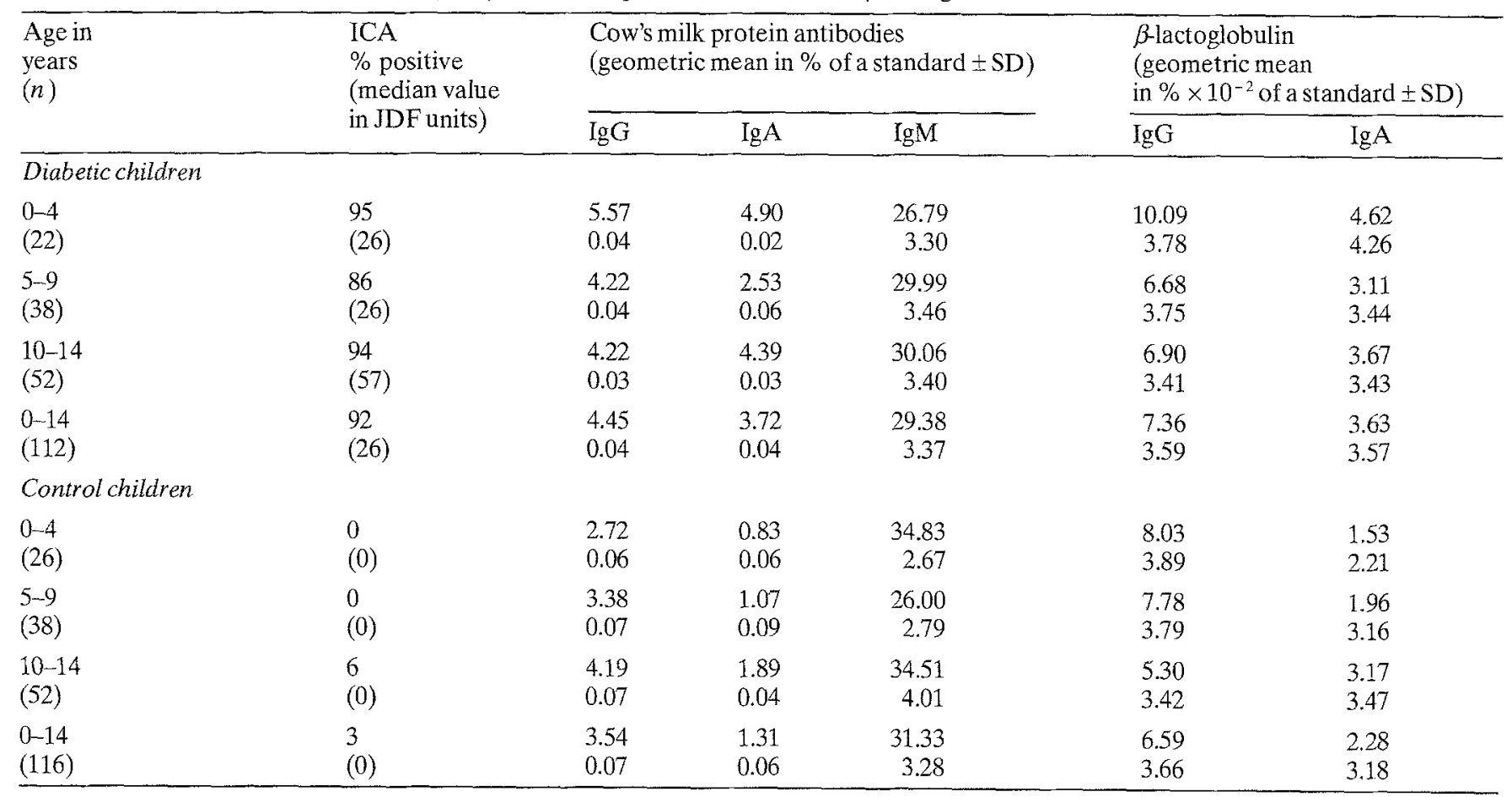

JDF units, Juvenile Diabetes Foundation units

In the present study we have examined without knowledge of the sample identity antibodies to $\beta$-lactoglobulin and other cow's milk proteins, in a large population-based case-control study of recent-onset diabetic children. The antibody levels were correlated to data on breast-feeding duration and introduction of cow's milk as well as to levels of ICA in order to answer the following questions: Are antibodies to cow's milk proteins risk determinants for childhood Type 1 diabetes? If so, is this increased risk dependent on an early exposure to cow's milk formula and a short breast-feeding duration? If so, is this increased risk independent of the level of ICA?

\section{Subjects and methods}

In a nationwide case-referent study covering all incident cases of Type 1 diabetes in Sweden, blood samples were collected from a total of 389 diabetic and 321 control children [10]. A blood sample was taken within 5 days after the diagnosis of diabetes. From a total of 710 serum samples we randomly selected (using random number tables) a sub-group of sera from 116 diabetic children ( 59 male/53 female) and 112 control children (60 male $/ 56$ female). The mean age of the diabetic children $\pm S D$ was $8.7 \pm 4.0$ years and for control children $8.7 \pm 4.3$ years. Data on the duration of breast-feeding and introduction of formula before 4 months of age were obtained from a mailed questionnaire [10]. Formula was defined as cow's milk formula without flour supplementation.

Sera were stored frozen at $-20^{\circ} \mathrm{C}$ until analysed for ICA and cow's milk protein antibodies. Islet cell cytoplasmic antibodies were analysed using an indirect two-colour immunofluorescence assay [11]. Sera were diluted 1:2, 1:4, 1:8 etc. until an end-point titre was found and levels converted to Juvenile Diabetes Foundation (JDF) units. All sera were tested without knowledge of sample identity in at least two separate assays. The ICA levels of the original group of 710 diabetic and control children have been reported previously [12].
Serum levels of antibodies to $\beta$-lactoglobulin and cow's milk proteins were measured without knowledge of sample identity using an ELISA-technique [9]. Background absorbance as determined in duplicate from absorbances of blocking solution coated wells was subtracted from that of the antigen coated wells which was a mean of triplicate measurements. The absorbance was compared to a standard of serially diluted sera with a very high titre of cow's milk protein and $\beta$-lactoglobulin antibodies. The levels of the antibodies are expressed as percent of the standard. The inter-assay coefficients of variance were as follows: cow's milk IgG $5.0 \%$, cow's milk IgA $13 \%$, $\beta$-lactoglobulin IgG $21 \%$ and $\beta$-lactoglobulin IgA $6.6 \%$. The detection limit for these antibodies was $0.02 \%$ of the standard and thus $\beta$-lactoglobulin IgG was measurable in $79 \%, \beta$-lactoglobulin IgA in $40 \%$, cow's milk IgG in $99 \%$, IgA in $97 \%$ and IgM in $96 \%$ of all samples.

\section{Statistical analysis}

To achieve a normal distribution the antibody levels of $\beta$-lactoglobulin and cow's milk proteins were log transformed. For calculations of ICA levels the titre steps (reciprocal log titre) were used i.e. $1: 2=1,1: 4=2,1: 8=3 \mathrm{etc}$. with negative set as 0 . For comparison between two groups we used Student's $t$-test for grouped data, for linear correlations Pearson's method and for multivariate analysis logistic regression analysis [13] using the antibody levels either as continuous or dichotomized variables. To test the goodness of fit of the models the likelihood ratio statistics was used [13]. Calculations were performed using the computer software QUEST (L. Gustafsson, University of Umeå, Umeå, Sweden) and EGRET (Epidemiological graphics estimation testing statistical and epidemiological research, Corp., Seattle, Wa., USA).

\section{Results}

Cow's milk antibodies and $\beta$-lactoglobulin antibodies are presented as geometric means in percent of standard and $\mathrm{SD}$ (Table 1). For all age groups the antibody levels except 
Table 2. Single correlation coefficients. Figures within parentheses denote $p$ values

\begin{tabular}{|c|c|c|c|c|c|c|c|c|}
\hline & Age & $\begin{array}{l}\text { Case-control } \\
\text { status }\end{array}$ & ICA & $\begin{array}{l}\text { Log } \beta \text {-lacto- } \\
\text { globulin } \operatorname{IgG}\end{array}$ & $\begin{array}{l}\text { Log } \beta \text {-lacto- } \\
\text { globulin IgA }\end{array}$ & $\begin{array}{l}\text { Log cow's } \\
\text { milk IgG }\end{array}$ & $\begin{array}{l}\text { Log cow's } \\
\text { milk IgA }\end{array}$ & $\begin{array}{l}\text { Log cow's } \\
\text { milk IgM }\end{array}$ \\
\hline Age & 1.0 & $\begin{array}{l}-0.01 \\
(0.88)\end{array}$ & $\begin{array}{c}0.04 \\
(0.56)\end{array}$ & $\begin{array}{c}-0.11 \\
(0.09)\end{array}$ & $\begin{array}{c}0.12 \\
(0.07)\end{array}$ & $\begin{array}{l}-0.01 \\
(0.87)\end{array}$ & $\begin{array}{c}0.11 \\
(0.09)\end{array}$ & $\begin{array}{c}0.02 \\
(0.81)\end{array}$ \\
\hline ICA & & & 1.0 & $\begin{array}{c}0.03 \\
(0.62)\end{array}$ & $\begin{array}{c}0.12 \\
(0.07)\end{array}$ & $\begin{array}{c}0.12 \\
(0.08)\end{array}$ & $\begin{array}{c}0.31 \\
(<0.001)\end{array}$ & $\begin{array}{l}-0.05 \\
(0.48)\end{array}$ \\
\hline $\log \beta$-lactoglobulin IgG & & & & 1.0 & $\begin{array}{c}0.23 \\
(<0.001)\end{array}$ & $\begin{array}{c}0.29 \\
(<0.001)\end{array}$ & $\begin{array}{c}0.33 \\
(<0.001)\end{array}$ & $\begin{array}{c}0.14 \\
(0.04)\end{array}$ \\
\hline $\log \beta$-lactoglobulin IgA & & & & & 1.0 & $\begin{array}{l}-0.02 \\
(0.78)\end{array}$ & $\begin{array}{c}0.06 \\
(0.36)\end{array}$ & $\begin{array}{c}0.13 \\
(0.05)\end{array}$ \\
\hline Log cow's milk IgG & & & & & & 1.0 & $\begin{array}{c}0.68 \\
(<0.001)\end{array}$ & $\begin{array}{c}0.35 \\
(0.001)\end{array}$ \\
\hline Log cow's milk IgA & & & & & & & 1.0 & $\begin{array}{c}0.22 \\
(<0.001)\end{array}$ \\
\hline
\end{tabular}

ICA, Islet cell antibodies

cow's milk IgM tended to be increased among diabetic children compared to control children. This was statistically significant only for cow's milk IgA antibodies ( $p<0.001,0-14$ years) and $\beta$-lactoglobulin IgA antibodies $(p<0.001,0-14$ years). The differences were especially evident in the age group $0-4$ years. In this group $\beta$-lactoglobulin $\operatorname{IgG}$ antibodies tended to differ $(p=0.1)$. ICA antibodies were found among $92 \%$ of the diabetic children vs $3 \%$ for the control children.

\section{Single correlations}

The cow's milk IgA antibodies significantly correlated to the ICA level and there was a tendency to a correlation between ICA level and cow's milk IgG antibodies as well as to the $\beta$-lactoglobulin IgA antibodies (Table 2). There were also significant correlations between cow's milk antibodies of different subclasses and IgG antibodies to $\beta$-lactoglobulin.

Breast-feeding duration was significantly inversely correlated to feeding of formula $(r=-0.63, p<0.001)$, the levels of $\beta$-lactoglobulin $\operatorname{IgG}(r=-0.16, p=0.04)$ and the logarithm of cow's milk protein IgA antibodies $(r=-0.17$, $p<0.001$ ). A positive correlation was also found between formula feeding and the $\beta$-lactoglobulin IgG antibodies $(r=0.22, p=0.01)$ and the cow's milk protein IgA antibodies $(r=0.16, p=0.04)$.

\section{Multiple regression analysis}

When introducing ICA and antibodies to $\beta$-lactoglobulin and cow's milk into a logistic regression model together with age it was found that ICA $(p<0.01), \operatorname{IgA}$ antibodies to $\beta$-lactoglobulin $(p=0.018)$ as well as IgA antibodies to cow's milk $(p=0.048)$ were independently related to an increased risk for Type 1 diabetes. The variables were used as continuous variables and the odds ratio increase was 2.63 for each ICA-titre step, 1.07 for each percent in- crease of $\beta$-lactoglobulin IgA antibodies and 1.001 for each percent increase of absorbance of cow's milk protein Ig A antibodies. Deviance on $216 d f$ for this model was 79.98 and the likelihood ratio statistics on $8 d f$ was $p<0.01$, meaning that the model fitted the data well.

To test the independence of antibodies as risk determinants to formula feeding all antibody levels were included in a model together with formula feeding (yes or no). In this model antibody levels were dichotomized using the geometric means +2 SD in the control children as the cutoff level for positivity of antibodies to cow's milk protein and $\beta$-lactoglobulin. It was then shown that both ICA and $\operatorname{Ig} A$ antibodies to $\beta$-lactoglobulin were significantly and independently related to an increased risk whereas cow's milk protein IgA antibodies were no longer significantly related to an increase in odds ratio (Table 3). The deviance of this model on $156 d f$ was 46.4 and the likelihood ratio statistics on $8 d f$ was $p<0.001$. Thus, the increase in

Table 3. Multiple logistic regression analysis on possible risk determinants for Type 1 (insulin-dependent) diabetes mellitus. Variables dichotomized (see Results)

\begin{tabular}{lllll}
\hline Variable & Odds ratio & $\begin{array}{l}\text { 95\% confidence } \\
\text { limits }\end{array}$ & $p$ value \\
\hline $\begin{array}{l}\text { Formula feeding } \\
\text { (yes/no) }\end{array}$ & 10.84 & 1.17 & 100.4 & 0.036 \\
$\begin{array}{l}\text { IgG antibodies to } \\
\beta \text {-lactoglobulin }\end{array}$ & 0.76 & 0.05 & 11.44 & 0.845 \\
$\begin{array}{l}\text { IgA antibodies to } \\
\beta \text {-lactoglobulin }\end{array}$ & 8.83 & 1.04 & 75.2 & 0.046 \\
$\begin{array}{l}\text { IgG antibodies to } \\
\text { cow's milk proteins }\end{array}$ & 0.65 & 0.006 & 70.6 & 0.856 \\
$\begin{array}{l}\text { IgA antibodies to } \\
\text { cow's milk proteins }\end{array}$ & 1.88 & 0.07 & 51.9 & 0.710 \\
$\begin{array}{l}\text { IgM antibodies to } \\
\text { cow's milk proteins }\end{array}$ & 0.21 & 0.0005 & 81.96 & 0.606 \\
\begin{tabular}{l} 
ICA \\
\hline
\end{tabular} & 1788 & 181.2 & $1764 \times 10^{5}$ & $<0.001$ \\
\hline
\end{tabular}

ICA, Islet cell antibodies 
cow's milk IgA antibodies among diabetic children seems to be dependent on an early introduction of formula or is confounded by other related exposures whereas the $\beta$-lactoglobulin $\operatorname{IgA}$ antibodies are associated with an increased odds ratio independent of all the other variables taken into account using this model.

\section{Discussion}

In this comparatively large population-based case-control study we have confirmed the previous report by Savilahti et al. [9] showing a significant increase in antibodies of the IgA class to both cow's milk protein and $\beta$-lactoglobulin in recent-onset Type 1 diabetes. For both types of antibodies the difference was most pronounced in children with onset of diabetes before 5 years of age compared to the age-matched control children. Several studies have shown that Type 1 diabetic children have a shorter duration of breast-feeding than healthy control children $[3,5,6]$ and a known relationship exists between an early introduction of cow's milk protein and levels of cow's milk protein antibodies of both the IgG and IgA classes $[14,15]$. These antibody titres may not be aetiologically related to the risk of childhood diabetes but rather confounded by other risk determinants related to an early weaning. In our study we found a significant correlation between both the duration of breast-feeding and the age of introduction of formula and levels of $\beta$-lactoglobulin IgG and cow's milk protein $\operatorname{IgA}$. Using a multiple logistic regression analysis, however, we could show that IgA antibodies to $\beta$-lactoglobulin were still significantly and independently related to an increased risk of Type 1 diabetes, whereas IgA antibodies to cow's milk protein were no longer significantly related to an increase in odds ratio. Thus, cow's milk protein antibodies may not be aetiologically related to Type 1 diabetes. However, this could be the case for $\beta$-lactoglobulin IgA, as $\beta$-lactoglobulin, which is one of the proteins present in cow's milk but not in human milk, has been shown to be highly antigenic [16]. Furthermore, structural homologies exist between $\beta$-lactoglobulin and a retinolbinding protein [17] which has been found in cells of human pancreatic islets [18].

The finding of increased antibody levels to cow's milk proteins, including $\beta$-lactoglobulin, could be a non-specific reaction to the acute autoimmune destruction of Beta cells at onset of diabetes. If this is the case these antibodies should be correlated to the titres of ICA. However, this was found only for cow's milk protein IgA antibodies and in the multiple regression analysis, these antibodies did not significantly contribute to the risk for diabetes when considering ICA. On the other hand, $\beta$-lactoglobulin IgA antibodies were independently related to the risk for diabetes which favours a more specific and independent relationship between Type 1 diabetes and increased levels of $\beta$-lactoglobulin antibodies.

It has also been suggested that an increase in cow's milk and $\beta$-lactoglobulin antibodies could be related to an excess intake of milk in children before the onset of diabetes. This is, however, contradicted by the finding of a decreased frequency of milk intake among diabetic compared to control children who reported on frequent intake of food and milk before the onset of Type 1 diabetes [19]. In fact, together with the present study this indicates that children who were exposed early to cow's milk based formula developed a clinical or subclinical cow's milk intolerance which later led to a decreased cow's milk intake.

In conclusion an early exposure to cow's milk formula is related to an increased risk for early-onset Type 1 diabetes. $\beta$-lactoglobulin IgA antibodies are significantly associated with an increased risk of diabetes at a young age independent of ICA levels and of an early introduction of cow's milk formula. In genetically susceptible children early exposure to $\beta$-lactoglobulin might be one trigger of the autoimmune process subsequently leading to early onset of Type 1 diabetes.

Acknowledgements. We thank Dr. L. Blom and Ms. M. Viikari for skillful technical assistance. This study was supported by grants from the Swedish Medical Research Council (project no.07531), the Swedish Diabetes Association and Nordisk Insulin Foundation.

\section{References}

1. Tattersall RB, Pyke DA (1972) Diabetes in identical twins. Lancet II: 1120-1125

2. Christau B, Kromann H, Ortved-Andersen O et al. (1977) Incidence, seasonal and geographical patterns of juvenile-onset insulin-dependent diabetes mellitus in Denmark. Diabetologia 13: 281-284

3. Blom L, Dahlquist G, Nyström L, Sandström A, Wall S (1989) The Swedish childhood diabetes study - social and perinatal risk determinants for diabetes in childhood. Diabetologia 32: 7-13

4. Scott FW (1990) Cow milk and insulin-dependent diabetes mellitus: is there a relationship? Am J Clin Nutr 51:489-491

5. Borch-Johnsen K, Mandrup-Poulsen T, Zachau-Christiansen B et al. (1984) Relation between breast feeding and incidence rates of insulin-dependent diabetes mellitus, Lancet II: 1083-1086

6. Mayer EJ, Hammar RF, Gay EC, Le Zotte DC, Savitz DA, Klingensmith GJ (1988) Reduced risk for IDDM among breast-fed children. Diabetes 37: 1625-1632

7. Elliott RB, Martin JM (1984) Dietary protein: a trigger of insulin-dependent diabetes in the BB rat? Diabetologia 26: 297 299

8. Daneman D, Fishman L, Clarson C, Martin JM (1987) Dietary triggers of insulin-dependent diabetes in the $\mathrm{BB}$ rat. Diabetes Res 5:93-97

9. Savilahti E, Ảkerblom HK, Tainio V-M, Koskimies S (1988) Children with newly diagnosed insulin-dependent diabetes mellitus have increased levels of cow's milk antibodies. Diabetes Res $7: 137-140$

10. Dahlquist G, Blom L, Tuvemo T, Nyström L, Sandström A, Wall S (1989) The Swedish childhood diabetes study - results from a nine year case register and a one year case-referent study indicating that Type 1 (insulin-dependent) diabetes mellitus is associated with both Type 2 (non-insulin dependent) diabetes mellitus and autoimmune disorders. Diabetologia 32:2-6

11. Landin-Olsson M, Sundkvist G, Lernmark $\AA$ (1987) Prolonged incubation in the two-colour immunofluorescence test increases the prevalence and titers of islet cell antibodies in type 1 (insulindependent) diabetes mellitus. Diabetologia 30: 327-332

12. Landin-Olsson M, Karlsson A, Dahlquist G et al. (1989) Islet cell and other organ-specific autoantibodies in all children developing type 1 (insulin-dependent) diabetes mellitus in Sweden during one year and in matched control children. Diabetologia 32: 387-395 
13. Breslow N, Day NE (1980) Statistical methods in cancer research. Vol 1 - The analysis of case-control studies. International Agency for Research on Cancer Scientific Publications, Lyon

14. Kletter B, Gery J, Freier S, Davies AM (1971) Immune responses of normal infants to cow milk. I. Antibodies type and kinetics of production. Int Archs Allergy Appl Immunol 40:656-666

15. Tainio V-M, Savilahti E, Arjomaa P, Salmenperä L, Perheentupa J, Siimes MA (1988) Plasma antibodies to cow's milk are increased by early weaning and consumption of unmodified milk, but production of plasma IgA and IgM cow's milk antibodies is stimulated even during exclusive breast-feeding. Acta Paediatr Scand 77: 807-811

16. Huang Q, Coleman JN, Stanworth DR (1985) Investigation of the allergenicity of $\beta$-lactoglobulin and its cleavage fragments. Int Archs Allergy Appl Immunol 78: 327-343

17. Pervaiz S, Brew K (1985) Homology of $\beta$-lactoglobulin, serum retinol-binding protein and protein HC. Science 228: 335-337
18. Kameko M, Ichikawa M, Kalsayama T, Kanai M, Kato M, Akamatsu T (1986) Immunohistochemical localization of plasma retinol-binding protein and pre-albumin in human pancreatic islets. Histochemical J 16: 164-168

19. Dahlquist G, Blom L, Persson L-Å, Sandström A, Wall S (1990) Dietary factors and the risk of developing insulin dependent diabetes in childhood. Br Med J 300: 1302-1306

Received: 5 March 1992

and in revised form: 10 June 1992

Dr. G. Dahlquist

Department of Pediatrics

University Hospital

S-901 85 Umeå

Sweden 